\title{
ANALISIS PENYEBARAN MERKURI PADA LAHAN BEKAS PENGOLAHAN EMAS TAMBANG RAKYAT DI KABUPATEN MINAHASA UTARA
}

\author{
Stefan Daniel Maramis ${ }^{1}$, Rika Ernawati ${ }^{2}$, Waterman Sulistyana Bargawa ${ }^{3}$, \\ Tedy Agung Cahyadi ${ }^{4}$, dan Edy Nursanto ${ }^{5}$ \\ UPN Veteran Yogyakarta, Magister Teknik Pertambangan, Indonesia ${ }^{1,2,3,4,5}$ \\ 12anielmaramis2@gmail.com, ${ }^{2}$ rika.ernawati@upnyk.ac.id, ${ }^{3}$ waterman.sb@upnyk.ac.id, \\ tedyagungc@upnyk.ac.id, ${ }^{4}$ edynursanto@upnyk.ac.id
}

\section{Diterima: \\ 26 Januari 2022 \\ Direvisi: \\ 14 Februari 2022 \\ Disetujui: \\ 15 Februari 2022}

\section{Abstrak}

Proses pengolahan emas secara tradisional yang diterapkan di daerah Tatelu Minahasa utara menggunakan teknologi sederhana dengan merkuri sebagai bahan penangkap emas melalui proses amalgamasi. Merkuri hasil pengolahan emas akan menyebar pada lingkungan di sekitarnya, jika merkuri terpapar pada tanah dalam jangka waktu lama maka racun ini akan menumpuk dan suatu saat akan menimbulkan gangguan kesehatan pada manusia. Penelitian ini bertujuan untuk mengetahui tingkat pencemaran dan penyebaran konsentrasi logam berat merkuri $(\mathrm{Hg})$ yang di indikasikan terdapat pada lahan di sekitar lokasi penelitian. Fokus penelitian ini yaitu untuk menganalisis penyebaran kontaminan Merkuri dalam tanah dengan menggunakan Metode Uji Mercury Analyzer untuk mengukur nilai kandungan Merkuri, Metode Geostatistik untuk menggambarkan distribusi pemodelan sebaran merkuri $(\mathrm{Hg})$ di Desa Tatelu dilakukan menggunakan metode Ordinary Kriging. Berdasarkan analisis semivariogram dihasilkan parameter estimasi menggunakan model Exponential. Parameter tersebut digunakan dalam estimasi menggunakan kriging. Sebaran merkuri $(\mathrm{Hg})$ pada lokasi yang tidak memiliki data pada daerah utara terlihat lebih rendah yaitu sekitar 0,16-1,07 mg/kg. Hal ini dipengaruhi kadar sampel pada lokasi tersebut relatif rendah. Sedangkan pada bagian selatan dapat dilihat penyebaran merkuri (Hg) lebih tinggi dengan rentang kadar yaitu sekitar 7,3-49,8 mg/kg.

Kata kunci: Pengolahan Emas, Logam Merkuri, Geostatistik

\begin{abstract}
The traditional gold processing process applied in the northern Minahasa Tatelu area uses simple technology with mercury as a gold catcher through an amalgamation process. Mercury from gold processing will spread to the surrounding environment, if mercury is exposed to the soil for a long time then this poison will accumulate and one day will cause health problems in humans. This study aims to determine the level of pollution and the distribution of the concentration of heavy metal mercury $(\mathrm{Hg})$ which is indicated to be found in the land around the research location. The focus of this research is to analyze the distribution of Mercury contaminants in the soil using the Mercury Analyzer Test Method to measure the value of the Mercury content, Geostatistical Methods to describe the distribution of mercury $(\mathrm{Hg})$ distribution in Tatelu Village using the Ordinary Kriging method. Based on semivariogram analysis, parameter estimation using the Exponential model is generated. These parameters are used in the estimation using kriging. The distribution of mercury $(\mathrm{Hg})$ in locations that do not have data in the northern region looks lower, around $0.16-1.07 \mathrm{mg} / \mathrm{kg}$. This is influenced by the relatively low sample rate at that location. While in the southern part, it can be seen that the distribution of mercury $(\mathrm{Hg})$ is higher with levels ranging from 7.3 to $49.8 \mathrm{mg} / \mathrm{kg}$.
\end{abstract}

Keywords: Gold Processing, Mercury Metal, Geostatistics
Maramis, S. D., Ernawati, R., Bargawa W. S., Cahyadi, T. A., \& Nursanto, E. (2022). Analisis Penyebaran Merkuri pada Lahan Bekas Pengolahan Emas Tambang Rakyat di Kabupaten Minahasa Utara. Jurnal Sosial dan Teknologi (SOSTECH), 2(2): 125-131 2774-5155

https://greenvest.co.id/ 


\section{PENDAHULUAN}

Kontaminan logam berat dalam tanah telah menjadi masalah serius secara global (Wan, Lei, \& Chen, 2016). Sejumlah logam berat berbahaya dapat masuk ke dalam tubuh manusia dari tanah yang terkontaminasi melalui jalur paparan seperti konsumsi langsung atau tidak langsung, penghirupan dan kontak kulit yang berpotensi berdampak pada kesehatan manusia (Engwa dkk, 2019) yang menyebabkan berbagai efek kesehatan, dan risiko kesehatan rumit oleh keadaan oksidasi dan perbedaan terkait dalam bioavailabilitas (Sonone dkk, 2020). Banyak sumber kontaminasi logam berat yang tersebar luas (Hanebuth et al, 2018). Memahami konsentrasi logam berat dalam skala regional sangat

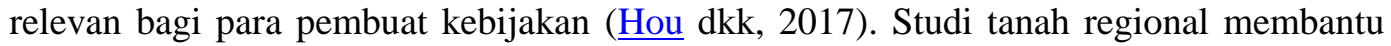
memandu tindakan dalam memerangi mata rantai polutan. Penting untuk memahami semua ketidakpastian mengenai konsentrasi kontaminan, bentuk, distribusi spasial dan perubahan temporal.

Proses pengolahan emas secara tradisional yang diterapkan di daerah Tatelu menggunakan teknologi sederhana dengan merkuri sebagai bahan penangkap emas melalui proses amalgamasi (Banunaek, 2016). Dalam aktivitas pengolahan emas ini digunakan metode amalgamasi (Kahhat dkk, 2019). Amalgamasi adalah proses ekstraksi emas dengan mencampurkan bijih emas dengan merkuri (Hg) (Balzino dkk, 2015). Dalam proses ini akan terbentuk ikatan senyawa antara Emas, Perak, dan Merkuri itu sendiri yang biasa dikenal sebagai amalgam ( $\mathrm{Au}-\mathrm{Hg})$ (Gnesin, 2015). Di satu sisi metode ekstraksi emas ini menguntungkan karena mudah dilakukan, efektif mengikat bijih emas dan mudah dibawa karena merkuri bersifat cair, akan tetapi penggunaan merkuri dengan metode amalgamasi ini akan memberi dampak membahayakan bagi lingkungan (Rodríguez \& López-Delgado, 2012). Merkuri adalah salah satu logam berat yang sangat beracun yang mudah terserap oleh media lingkungan di sekitarnya (Raj \& Maiti, 2019). Racun Merkuri ini adalah racun yang kumulatif, dalam arti bila lingkungan di sekitarnya terpapar dalam jangka waktu lama maka racun ini akan menumpuk dan suatu saat akan menimbulkan gangguan kesehatan pada manusia (Balali-Mood dkk, 2021).

Penelitian terdahulu yang menjadi pertimbangan peneliti untuk melakukan penelitian ini yaitu penelitian yang dilakukan oleh Wawo dkk, (2017) yang mana dalam penelitian tersebut menggunakan metode AAS (Atomic Absorption Spectrophotometer) dan ditemukan hasil penelitian bahwa tanah yang berada disekitar pertambangan rakyat telah mencemari lingkungan, sedangkan tanah yang berada dekat sungai masuk dalam konsentrasi normal. Penelitian yang dilakukan oleh Mirdat dkk, (2013), dengan menggunakan metode metode survey dan analisis laboratorium. Hasil penelitian menunjukkan bahwa kandungan merkuri pada semua sampel tanah dan tailing sangat tinggi dari ambang batas yang di tentukan. Penelitian yang dilakukan oleh Kitong dkk, (2012), yaitu menggunakan metode Cold Vapor-Atomic Absorption Spectrometry (CVAAS) dan Atomic Absorption Spectrometry (AAS). Dari hasil penelitian ini menunjukkan konsentrasi total merkuri dan arsen tertinggi adalah di Desa Karimbow I yang merupakan daerah pertambangan emas rakyat. Berdasarkan penelitian tersebut peneliti melakukan penelitian menggunakan metode uji Mercury Analyzer dan metode geostatistik yaitu metode kriging untuk menganalisis penyebaran logam merkuri pada area penelitian.

Dapat diperhatikan dari bahaya yang ditimbulkan oleh logam berat merkuri $(\mathrm{Hg})$ jika terakumulasi dalam tanah dan sedimen, maka dalam hal ini perlu dilakukan analisis tingkat pencemaran logam berat pada tanah dan kualitas sedimen yaitu analisis kualitas tanah dan sedimen. berdasarkan data kandungan logam berat dengan menggunakan beberapa indikator. yang dapat dikelompokkan menjadi satu indeks. Metode yang digunakan untuk menganalisis penyebaran cemaran merkuri adalah metode Kriging. Bobot kriging diperoleh dari estimasi varians minimum dengan memperluas penggunaan semivariogram. Penduga kriging adalah penduga tak bias dan jumlah semua bobot adalah satu. Bobot ini digunakan untuk memperkirakan nilai ketebalan, tinggi, grade atau 
variabel lainnya (Bargawa, 2020). Dalam perkembangannya, banyak metode kriging yang digunakan untuk menyelesaikan berbagai kasus dalam data geostatistik, misalnya terdapat sampel kandungan mineral yang tidak memiliki kecenderungan tertentu. Metode kriging yang cocok untuk menyelesaikan kasus ini adalah kriging biasa karena metode ini dapat digunakan ketika mean populasi tidak (Bargawa, 2020). Oleh karena itu, penelitian ini bertujuan untuk mengetahui tingkat pencemaran dan sebaran konsentrasi logam berat merkuri $(\mathrm{Hg})$ yang terindikasi terdapat pada lahan sekitar lokasi penelitian. Sehingga hasil penelitian dapat bermanfaat sebagai referensi atau acuan peta penyebaran kontaminan merkuri dalam tanah akibat kegiatan pengolahan emas tradisional di Desa Tatelu dalam skala kecil maupun dalam skala yang lebih luas. penelitian ini juga dapat bermanfaat apabila diperlukan suatu strategi pengelolaan dan pemulihan lingkungan.

\section{METODE PENELITIAN}

Metode dalam penelitian ini meliputi tahap persiapan, tinjauan pustaka, dan aspekaspek yang terkait dengan penelitian yang akan dilakukan. Kemudian melakukan pengenalan dan observasi langsung di lapangan objek penelitian. Survei lapangan, metode ini merupakan suatu metode pengamatan, pencatatan, dan pengukuran untuk memperoleh data dan karakteristik lahan yang diamati secara langsung, pada tahap ini dilakukan random sampling. Sampel yang diambil adalah sampel tanah/sedimen sebanyak 20 sampel tanah. Titik pengambilan sampel ditentukan berdasarkan lokasi tambang dengan radius area $100 \mathrm{~m} 2$ di sekitar penambangan dan pengolahan emas rakyat yang diperkirakan berpotensi terjadinya pencemaran, metode pengambilan sampel tanah adalah dengan menggunakan metode zigzag pada lapisan tanah pucuk yaitu pada kedalaman $30 \mathrm{~cm}$ dari permukaan tanah.

Setelah pengambilan sampel dilakukan Metode uji laboratorium bertujuan untuk menguji kandungan logam berat yang terdapat pada sampel tailing dan sedimen yang berada di lokasi penelitian menggunakan Metode uji Mercury Analyzer Hasil Uji lab konsentrasi logam berat yang di dapat dari laboratorium analisis Mercury Analyzer kemudian dilakukan analisis yaitu, Analisis Statistik Deskriptif, Analisis Statistik Spasial, dan Analisis Penyebaran Logam Berat Menggunakan Metoda Geostatistik (Ordinary Kriging).

\section{HASIL DAN PEMBAHASAN}

Pengambilan sampel dilakukan di Desa Tatelu, Kecamatan Dimembe, Kabupaten Minahasa Utara, Provinsi Sulawesi Utara. Lahan pada lokasi pengambilan sampel merupakan lahan bekas pengolahan emas yang sudah tidak beroperasi selama 10 tahun. Meskipun sudah 10 tahun tetapi lahan tersebut masih terdapat kandungan merkuri $(\mathrm{Hg})$. Penelitian ini menggonakan metode kriging sebagai estimator yang akurat setelah dilakukan eksperimental terhadap dua metode yaitu IDW dan Ordinary Kriging. Hasil cross validation menunjukan bahwa IDW memiliki nilai ME dan RMSE yang sangat besar.

Pad metode Geostatistik terdapat dua faktor yang menentukan bentuk sebaran, yaitu nilai (bobot) dan jarak. Nilai ditentukan dengan metode pengambilan sampel dan analisis, sedangkan jarak ditentukan oleh penentuan lokasi pengambilan sampel. Nilai dan jarak ini membentuk dasar untuk korelasi spasial antara titik sampel. Karakter anisotropik (perbedaan nilai untuk arah yang berbeda) dapat dihitung berdasarkan variogram yang dihasilkan. Dengan variogram maka kuantifikasi nilai di antara dua conto data yang berbeda nilai dan terpisah pada jarak tertentu dapat ditentukan. Fitting variogram dilakukan untuk mencocokan variogram eksperimental dengan variogram teoritis. Ada 3 model variogram yang digunakan yaitu spherical, eksponential dan gaussian. 


\section{Basis Data}

Basis data assay adalah data hasil analisis laboratorium yang digunakan sebagai dasar dalam pemodelan penyebaran kontaminan Merkuri dalam tanah. Hasil analisis laboratorium untuk konsentrasi Merkuri pada conto tanah dapat dilihat berdasarkan tabel 1 berikut.

Tabel 1. Konsentrasi Merkuri dalam conto tanah

\begin{tabular}{cccc}
\hline Sampel & $\mathbf{X}$ & $\mathbf{Y}$ & $\mathbf{H g}$ \\
\hline A-01 & 721891.164 & 10170122.345 & 0.17 \\
A-02 & 721905.074 & 10170124.509 & 0.45 \\
A-03 & 721919.603 & 10170127.287 & 0.19 \\
B-01 & 721814.810 & 10170108.449 & 1.13 \\
C-01 & 721878.832 & 10170084.546 & 0.53 \\
C-02 & 721893.371 & 10170076.265 & 0.23 \\
C-03 & 721910.381 & 10170070.751 & 1.75 \\
D-01 & 721867.743 & 10170039.989 & 49.8 \\
E-01 & 721970.9438 & 10170108.29 & 1.1 \\
E-02 & 721953.3168 & 10170112.57 & 5.13 \\
E-03 & 721935.3824 & 10170115.01 & 1.61 \\
F-01 & 722206.7227 & 10169908.2 & 46.3 \\
F-02 & 722193.4324 & 10169903.58 & 1.04 \\
G-01 & 722171.485 & 10169899.26 & 0.78 \\
H-01 & 722167.5217 & 10169839.35 & 2.31 \\
H-02 & 722176.1883 & 10169828.91 & 0.81 \\
H-03 & 722187.0195 & 10169818.17 & 2.61 \\
I-01 & 722374.4708 & 10170051.83 & 0.09 \\
I-02 & 722361.1572 & 10170072.09 & 0.79 \\
I-03 & 722349.0804 & 10170092.36 & 0.11 \\
\hline SU
\end{tabular}

Sumber : Lab. SGS WLN Manado

Berdasarkan tabel di atas yang dibaca sebagai konsentrasi Merkuri adalah kolom $\mathrm{Hg}$ $(\mathrm{mg} / \mathrm{kg})$. Umumnya satuan ini juga sering disebut dengan satuan ppm yang artinya adalah part per million atau satu per $1,000,0000 . \mathrm{Mg} / \mathrm{kg}$ adalah sama dengan $1 / 1,000,000$ karena satu kilogram sama dengan 1,000,000 mg. Sebagai contoh nilai konsentrasi Merkuri pada C-03 adalah $1,75 \mathrm{mg} / \mathrm{kg}$ maka angka tersebut menjelaskan bahwa dalam $1 \mathrm{Kg}$ conto tanah WS-20 terdapat $1,75 \mathrm{mg}$ unsur Merkuri.

\section{Analisis Statistik}

Analisis statistik dilakukan terhadap data assay dan komposit. Analisis ini bertujuan untuk mengetahui bentuk distribusi data yang digunakan. Tabulasi statistik data dapat dilihat pada tabel 2 dibawah ini

Tabel 2. Analisis Statistik Kadar Merkuri

\begin{tabular}{lc}
\hline \multicolumn{1}{c}{ Parameter } & Value \\
\hline Minimum Value & 0,09 \\
Maximum Value & 49,80 \\
2nd Highest & 46,30 \\
3rd Highest & 5,13 \\
4th Highest & 2,61 \\
$N$ & 20 \\
Mean & 5,85 \\
Variance & 210,02 \\
Standard Deviation & 14,49 \\
Coeff. of Variation & 2,48
\end{tabular}




\begin{tabular}{lr} 
Median & 0,93 \\
Skewness & 2,86 \\
Kurtosis & 6,98 \\
\hline \multicolumn{2}{l}{ Sumber: Aplikasi ArcGis 10.8 }
\end{tabular}

\section{Analisis Statistik Spasial}

Analisis variogram dilakukan untuk mengetahui karakteristik korelasi spasial atau tingkat kemiripan (variabilitas) dari data kadar Merkuri di daerah penelitian. Parameter arah yang digunakan berdasarkan proses eksperimental yang dilakukan pada berbagai arah. Fitting variogram dilakukan untuk membandingkan antara model variogram teoritis dengan variogram eksperimental. Hasil fitting variogram dapat dilihat pada gambar 1 sampai gambar 3 di bawah ini

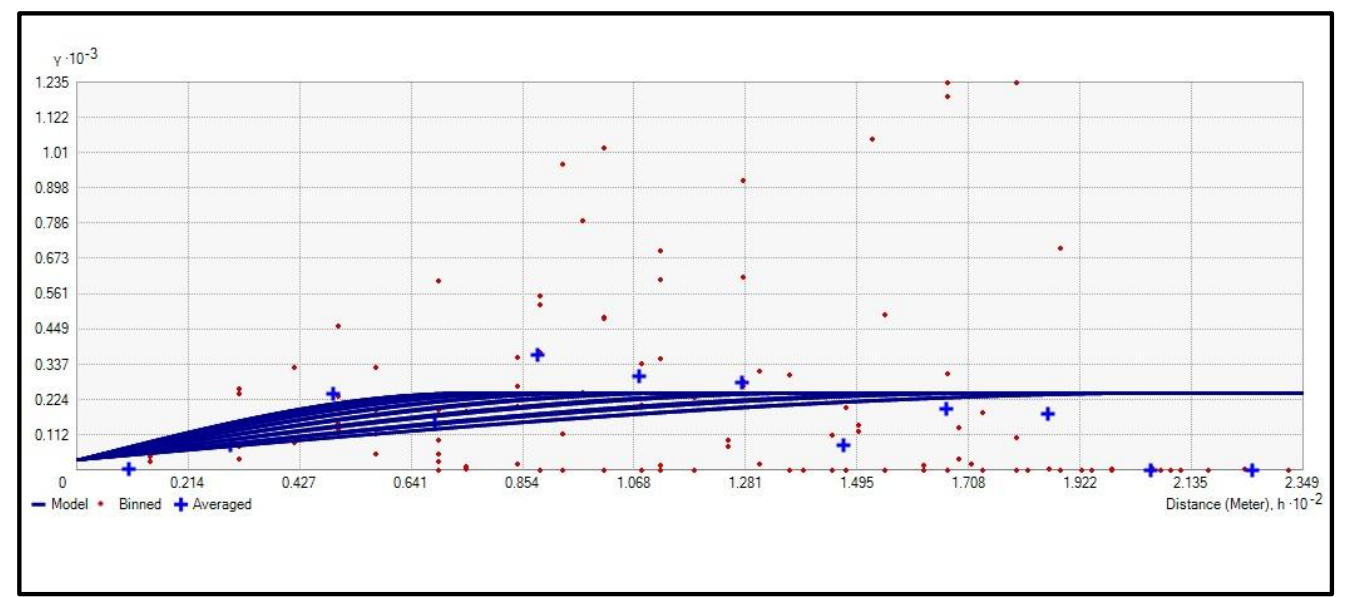

Gambar 1 Fitting variogram model spherical (Sumber: ArcGis 10.8)

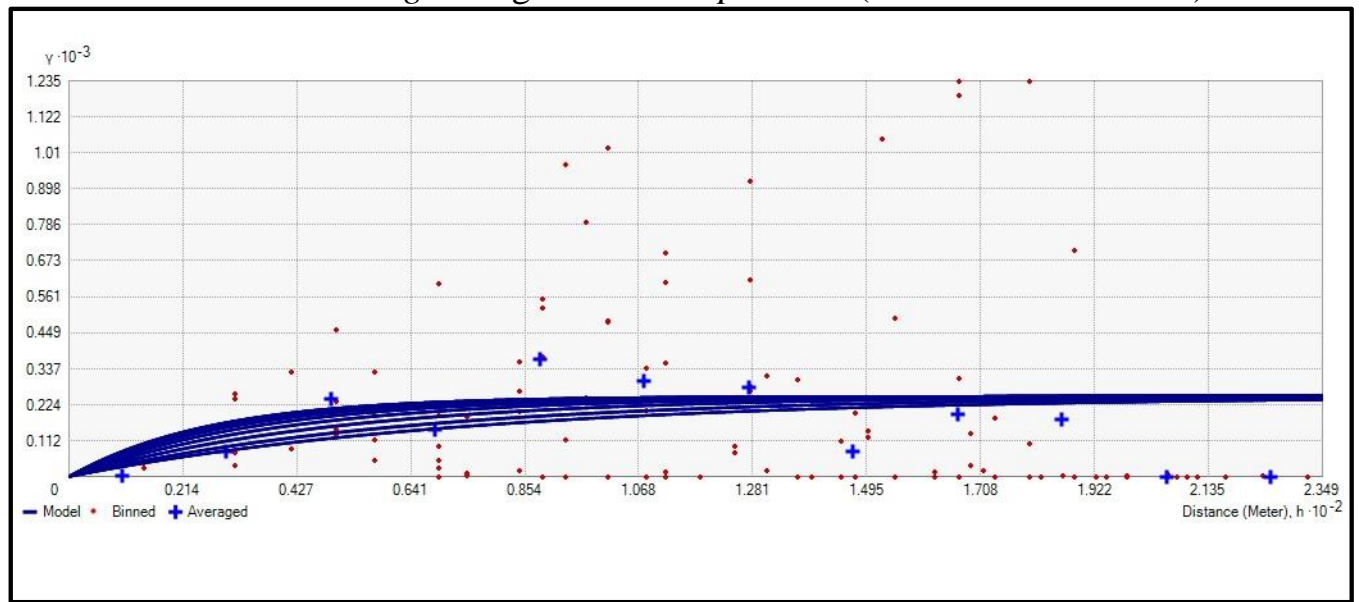

Gambar 2 Fitting variogram model exponential (Sumber: ArcGis 10.8)

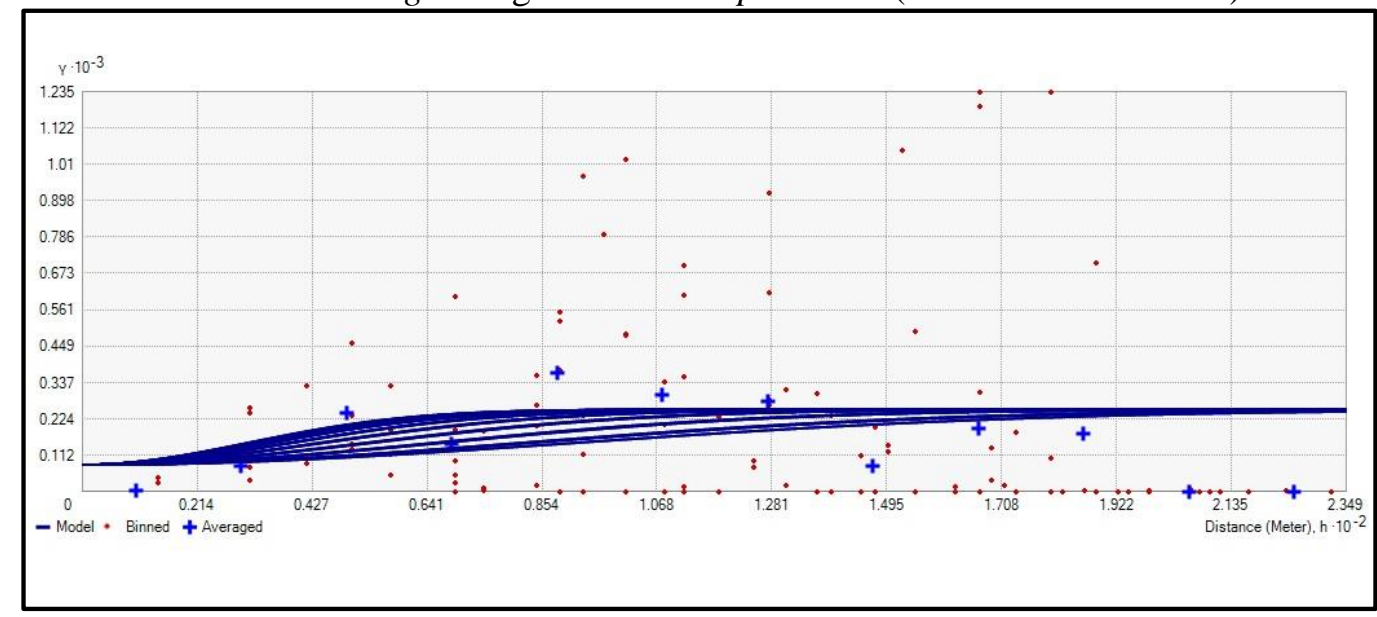

Gambar 3 Fitting variogram model Gaussian (Sumber: ArcGis 10.8) 
Berdasarkan analisis semivariogram yang telah ditentukan diperoleh parameter nugget, sill, range (major range dan minor range), dan arah sumbu distribusi data. Hasil data analisis semivariogram terlihat Pada berikut.

Tabel 3 Parameter pemodelan semivariogram

\begin{tabular}{lccccccc}
\hline $\begin{array}{c}\text { Variogram } \\
\text { Model }\end{array}$ & $\begin{array}{c}\text { Main } \\
\text { Direction }\end{array}$ & \multicolumn{2}{c}{ Range $(\boldsymbol{m})$} & Nugget & sill & ME & \multirow{2}{*}{ RMSE } \\
\hline Spherical & $123^{0}$ & 222,6 & 74,8 & 30,99 & 214 & 0,037 & 0,97 \\
Exponential & $115^{0}$ & 234,87 & 78,93 & 0,01 & 251 & 0,035 & 0,95 \\
Gaussian & $150^{\circ}$ & 222,6 & 75 & 82 & 170,5 & 0,008 & 1,23 \\
\hline
\end{tabular}

Keterangan $: M E=$ Mean Error, $R M S E=$ Root Mean Square Error

Sumber : ArcGis 10.8

Berdasarkan tabel perbandingan model variogram langkah selanjutnya adalah menentukan model yang terbaik berdasarkan parameter ME (Median Error) dan RMSE (Root Mean Square Error). ME atau Mean Error sering digunakan untuk menaksir ketepatan pada mean data. Dalam perhitungan ME berdistribusi normal dengan mean dan varians. Jadi penaksir mean bertambah dengan meningkatnya ukuran conto. Sedangkan RMSE atau Root Mean Square Error adalah nilai penaksiran terhadap standar deviasi dari suatu conto. Hasil estimasi dianggap akurat apabila nilai ME mendekati 0 (nol) dan nilai RMSE semakin kecil. Berdasarkan tabel 3 diatas model eksponential memiliki hasil yang lebih akurat dibanding model yang lain. Model eksponential memiliki nilai ME 0,035 dan RMSE 0,95. Sedangkan model spherical menghasilkan ME 0,037 dan RMSE 0,97 dan model gaussian menghasilkan ME 0,008 dan RMSE 1,23. Model spherical memiliki nilai ME dan RMSE yang tidak jauh berbeda dengan exponential, tapi nilai nugget pada model spherical tinggi yaitu 30,99. Nilai nugget yang tinggi menunjukkan tingkat variasi makin tinggi pula, dan nugget yang paling tinggi adalah model gaussian yaitu 82. Nilai nugget yang paling rendah adalah model exponential yaitu 0,01 sehingga model exponential adalah model yang akurat digunakan.

\section{Peta Penyebaran Kontaminan Merkuri}

Berdasarkan hasil analisis semivariogram yang telah melalui tahapan-tahapan di atas dan interpolasi variabel data maka penyebaran konsentrasi Merkuri dipresentasikan sebagaimana pada Gambar 4 Peta penyebaran pencemaran kontaminan Merkuri di Desa Tatelu, Kec. Minahasa Utara 


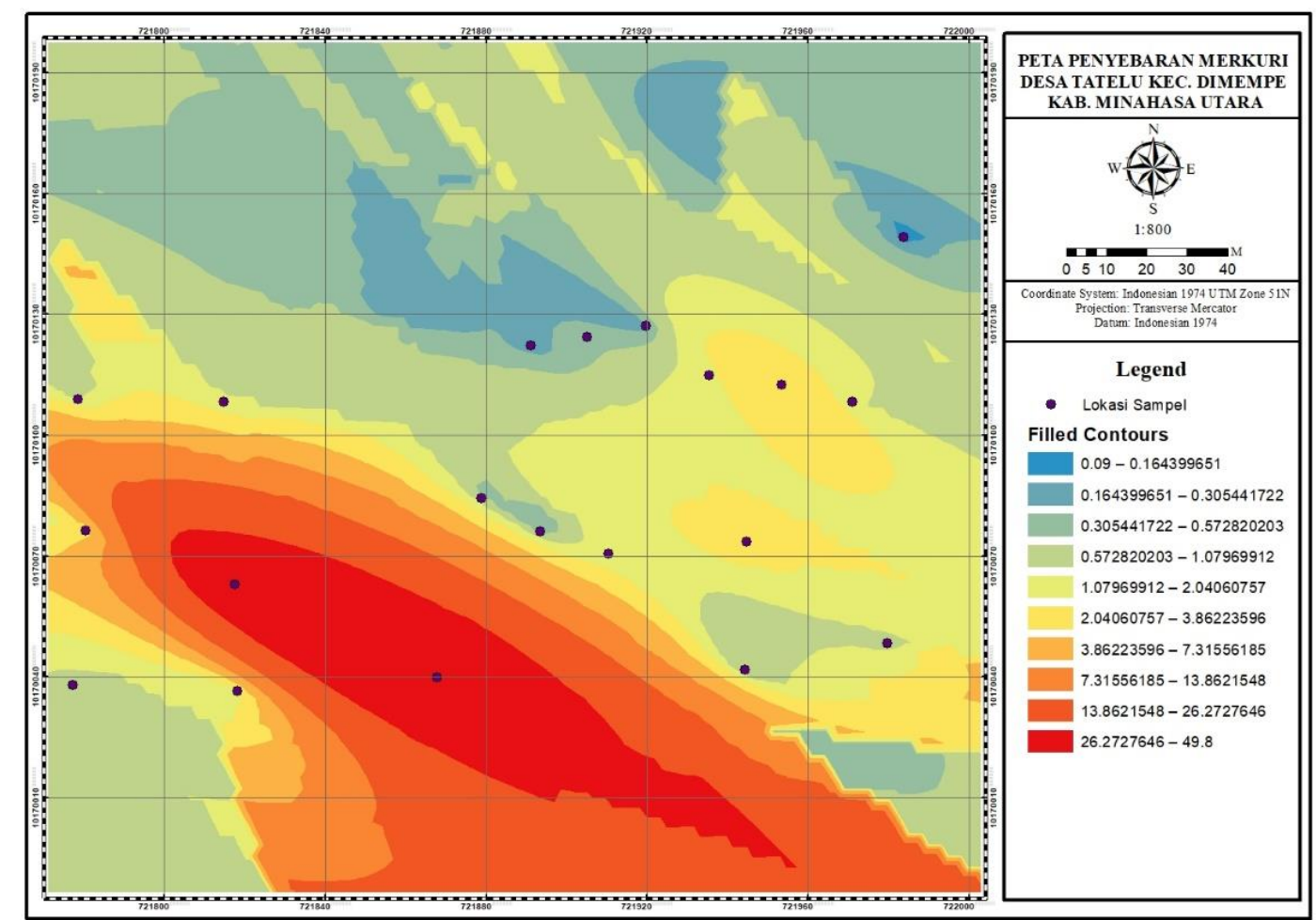

Gambar 4 Penyebaran Kontaminan Merkuri di Desa Tatelu (Sumber: Aplikasi ArcGis 10.8)

Terlihat pada gambar di atas terjadi interpolasi kontinyu dari titik-titik conto yang menyebabkan beberapa lokasi tanpa data di lapangan menunjukkan nilai pada range data. Penyebaran pencemaran Merkuri dilakukan dengan interpolasi terhadap nilai statistik ratarata sehingga lokasi tanpa data menjadi memiliki nilai. Peta penyebaran pencemaran Merkuri menunjukkan warna kuning pada sebagian besar lokasi sekitar data, dan warna biru di lokasi tanpa data. Sedangkan terdapat warna merah pada titik tertentu, warna merahorange ini menunjukan kadar mekuri yang tinggi yaitu pada range 7,3-49,8 mg/kg. Sedangkan warna biru adalah data dengan range $0,09-0,3 \mathrm{mg} / \mathrm{kg}$ dan warna kuning dengan range $1-3,6 \mathrm{mg} / \mathrm{kg}$. Hal ini muncul dikarenakan metode ini terbatas pada pendistribusian data pada range konsentrasi Merkuri terendah hingga tertinggi yaitu 0,09-49,8 mg/kg

\section{KESIMPULAN}

Pemodelan sebaran merkuri $(\mathrm{Hg})$ di Desa Tatelu dilakukan menggunakan metode Ordinary Kriging. Berdasarkan analisis semivariogram dihasilkan parameter estimasi menggunakan model Exponential. Parameter tersebut digunakan dalam estimasi menggunakan kriging. Sebaran merkuri $(\mathrm{Hg})$ pada lokasi yang tidak memiliki data pada daerah utara terlihat lebih rendah yaitu sekitar $0,16-1,07 \mathrm{mg} / \mathrm{kg}$. Hal ini dipengaruhi kadar sampel pada lokasi tersebut relatif rendah. Sedangkan pada bagian selatan dapat dilihat penyebaran merkuri ( $\mathrm{Hg})$ lebih tinggi dengan rentang kadar yaitu sekitar 7,3 - 49,8 mg/kg. Lahan bekas pengolahan emas tergolong lahan yang tercemar sehingga perlu dilakukan penelitian lanjutan tentang pengolahan lahan tercemar

\section{DAFTAR PUSTAKA}

Balali-Mood, Mahdi, Naseri, Kobra, Tahergorabi, Zoya, Khazdair, Mohammad Reza, \& Sadeghi, Mahmood. (2021). Toxic mechanisms of five heavy metals: mercury, lead, chromium, cadmium, and arsenic. Frontiers in Pharmacology, 12.

Balzino, Michela, Seccatore, Jacopo, Marin, Tatiane, De Tomi, Giorgio, \& Veiga, Marcello M. (2015). Gold losses and mercury recovery in artisanal gold mining on the Madeira River, Brazil. Journal of Cleaner Production, 102, 370-377.

Banunaek, Zofar Agluis. (2016). Pencemaran Merkuri di Lahan Pertambangan Emas Rakyat Dan Strategi Pengendaliannya. Institut Teknologi Sepuluh Nopember 
Surabaya.

Bargawa, Waterman Sulistyana. (2020). Simulasi Perubahan Model Variogram Untuk Estimasi Memakai Teknik Block Kriging. Jurnal Teknologi Pertambangan, 6(1).

Engwa, G. Azeh, Ferdinand, P. Udoka, Nwalo, F. Nweke, \& Unachukwu, Marian N. (2019). Mechanism and health effects of heavy metal toxicity in humans. Poisoning in the Modern World-New Tricks for an Old Dog, 10.

Gnesin, G. G. (2015). Metals and Alloys of Bronze Age: from Middle to Modern Times.

II. Gold, Silver, Tin, Lead, Mercury, and Their Alloys. Powder Metallurgy and Metal Ceramics, 53(11), 722-732.

Hou, Deyi, O'Connor, David, Nathanail, Paul, Tian, Li, \& Ma, Yan. (2017). Integrated GIS and multivariate statistical analysis for regional scale assessment of heavy metal soil contamination: A critical review. Environmental Pollution, 231, 1188-1200.

Kahhat, Ramzy, Parodi, Eduardo, Larrea-Gallegos, Gustavo, Mesta, Carlos, \& VázquezRowe, Ian. (2019). Environmental impacts of the life cycle of alluvial gold mining in the Peruvian Amazon rainforest. Science of The Total Environment, 662, 940-951.

Kitong, Melin T., Abidjulu, Jemmy, \& Koleangan, Harry S. (2012). Analisis merkuri (Hg) dan arsen (As) di sedimen sungai Ranoyapo kecamatan Amurang Sulawesi Utara. Jurnal MIPA, 1(1), 16-19.

Mirdat, S., Pata'dungan, Yosep S., \& Isrun, B. (2013). Status logam berat merkuri (Hg) dalam tanah pada kawasan pengolahan tambang emas di kelurahan Poboya, Kota Palu. Tadulako University.

Raj, Deep, \& Maiti, Subodh Kumar. (2019). Sources, toxicity, and remediation of mercury: an essence review. Environmental Monitoring and Assessment, 191(9), 122.

Rodríguez, Olga, Padilla, Isabel, Tayibi, Hanan, \& López-Delgado, Aurora. (2012). Concerns on liquid mercury and mercury-containing wastes: A review of the treatment technologies for the safe storage. Journal of Environmental Management, 101, 197-205.

Sonone, Swaroop S., Jadhav, Swapnali, Sankhla, Mahipal Singh, \& Kumar, Rajeev. (2020). Water contamination by heavy metals and their toxic effect on aquaculture and human health through food Chain. Letters in Applied NanoBioScience, 10(2), $2148-2166$.

Wan, Xiaoming, Lei, Mei, \& Chen, Tongbin. (2016). Cost-benefit calculation of phytoremediation technology for heavy-metal-contaminated soil. Science of the Total Environment, 563, 796-802.

Wawo, Rahmah Hidayanti Andi, Widodo, Sri, Jafar, Nurliah, \& Yusuf, Firman Nullah. (2017). Analisis Pengaruh Penambangan Emas Terhadap Kondisi Tanah pada Pertambangan Rakyat Poboya Palu, Provinsi Sulawesi Tengah. Jurnal Geomine, $5(3)$.

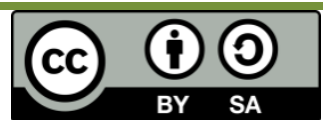

This work is licensed under a Creative Commons Attribution-ShareAlike 4.0 International License 